\title{
The Dissemination of European Popular Print: Exploring Comparative Approaches
}

\author{
Jeroen Salman \\ Assistant Professor Comparative Literature, University of Utrecht, Utrecht, \\ Netherlands \\ j.salman@uu.nl
}

\begin{abstract}
This article discusses the prospects of a comparative approach within the field of the dissemination of European popular print. Currently, it is still hard to find studies that address distribution of popular print with a Europe-wide scope. After an introduction about the main concepts, models and approaches, the article discusses some topic related issues, questions, approaches and sources. Social and professional categorisations are explored, as well as the differences between urban and rural distribution, the impact of regional and international networks, the effects of trade regulations and the collaborative features of distribution practices. What became clear is that a wideranging study that includes all European countries is urgently needed but not within reach soon, due to a lack of fundamental research and assessible sources. We should therefore first start to collect data systematically and conduct a series of comparative case studies in which we explore important questions and approaches.
\end{abstract}

\section{Keywords}

popular print - dissemination - comparative approach - Europe - itinerant and sedentary booksellers

\section{State of the Art}

In the field of European book history, the dissemination of popular print is still little studied, and particularly from a comparative perspective. We do find 
edited volumes where different countries are studied side by side, ${ }^{1}$ but more integrated, comparative approaches are rare. Even within the field of popular print culture itself, it remains a challenge to find studies that address distribution of popular print with a Europe-wide scope. Consequently we tend to refer to a small group of works, such as the seminal book of Laurence Fontaine from 1993 about French pedlars from the Alps who crossed many European borders carrying books and other goods in their packs. ${ }^{2}$ Colportage et lecture populaire (1996) edited by Roger Chartier and Hans-Jürgen Lüsebrink, is also widely used, although it contains only a few contributions about 'colporteurs' who crossed national borders. ${ }^{3}$ Much referred to is the pioneering work of Alberto Milano and others on the Italian Tesini pedlars who distributed the famous Remondini prints to every corner of Europe. ${ }^{4}$ And for Northern Europe, the present author has made a systematic comparison between the English and Dutch itinerant distribution system. ${ }^{5}$ The recent work of Joad Raymond and others on news networks has stressed the transnational features of news dissemination. ${ }^{6}$

Alongside these international perspectives we should not neglect many excellent regional and local studies. They have been, and still are, a solid and necessary foundation and inspiration for transnational explorations. In England and Scotland Margaret Spufford inspired a whole generation of scholars with her work on pedlars and hawkers selling textiles alongside cheap

1 D. Atkinson \& S. Roud (eds.), Street Literature of the Long Nineteenth Century: Producers, Sellers, Consumers (Cambridge 2017); D. Atkinson \& S. Roud, Cheap Print and the People: European Perspectives on Popular Literature (Newcastle upon Tyne 2019). All links were last accessed 10/og/2020.

2 L. Fontaine, Histoire du colportage en Europe (XVe-XIX siècles) (Paris 1993); English translation: History of Pedlars in Europe (Cambridge 1996).

3 R. Chartier \& H.-J. Lüsebrink (eds.), Colportage et lecture populaire: Imprimés de large circulation en Europe XVI ${ }^{e}-X I X^{e}$ siècle (Paris 1996).

4 A. Milano (ed.), Commercio delle stampe e diffusione delle immagini nei secoli XVIII e XIX: Trade and Circulation of Popular Prints during the XVIII and XIX Centuries (Rovereto 2008); A. Boschloo, 'Reizende prentverkopers in dienst van de Remondini', in: Reizen en reizigers in de Renaissance: Eigen en vreemd in oude en nieuwe werelden, ed. K. Enenkel et al. (Amsterdam 1998), pp. 97-116.

5 J. Salman, Pedlars and the Popular Press: Itinerant Distribution Networks in England and The Netherlands 1600-1850 (Boston and Leiden 2014). See also R. Harms, J. Raymond \& J. Salman (eds.), Not Dead Things: The Dissemination of Popular Print in England and Wales, Italy, and the Low Countries, 1500-1820 (Boston and Leiden 2013).

6 N. Moxham \& J. Raymond (eds.), News Networks in Early Modern Europe (Boston and Leiden 2016). 
books. ${ }^{7}$ Similarly, scholars in France, Germany and Spain have tried to reconstruct regional networks of itinerant traders from the sixteenth to the nineteenth century. ${ }^{8}$ In-depth studies that concentrate on the complex dynamics of urban street trade have been very fruitful. ${ }^{9}$ From a different angle, studies on popular genres such as pamphlets, ballads, jestbooks, almanacs and penny prints, often include sections on the different modes of distribution. ${ }^{10}$ Underrepresented in all this ongoing work, partly due to language barriers, are studies on Scandinavia and Eastern Europe. ${ }^{11}$ The overview presented in what follows is therefore inevitably largely limited to studies on Southern and Northern Europe.

M. Spufford, The Great Reclothing of Rural England: Petty Chapmen and Their Wares in the Seventeenth Century (London 1984). See also M. Spufford, 'The Pedlar, the Historian and the Folklorist: Seventeenth Century Communications', Folklore, 105 (1994), pp. 13-24; M. Spufford, Small Books and Pleasant Histories. Popular Fiction and its Readership in Seventeenth-Century England (Cambridge 1981); T. Watt, Cheap Print and Popular Piety, 1550-1640 (Cambridge 1994); T. Watt, 'Publisher, Pedlar, Pot-Poet: The Changing Character of the Broadside Trade, 1550-1640', in: Spreading the Word: The Distribution Networks of Print, 1550-1850, ed. R. Myers \& M. Harris (Winchester 1990); R. Myers, M. Harris \& G. Mandelbrote (eds.), Fairs, Markets and the Itinerant Book Trade (New Castle 2007); V. Dunstan, 'Chapmen in Eighteenth-Century Scotland', Scottish Literary Review, 9 (2017), pp. 41-57.

$8 \quad$ P. Brochon, Le livre de colportage en France depuis le XVI e siècle: Sa littérature, ses lecteurs (Paris 1954); C. Griffin, Journeymen-Printers, Heresy, and the Inquisition in Sixteenth-Century Spain (Oxford 2005); G. Scheidt, Der Kolportagebuchhandel (1869-1905): Eine systemtheoretische Rekonstruktion (Stuttgart 1994).

9 R. Salzberg, Ephemeral City. Cheap Print and Urban Culture in Renaissance Venice (Manchester 2014); L. Carnelos, 'Cheap Print and Street Sellers in Early Modern Italy', in: Atkinson \& Roud (eds.) op. cit. (n. 1: 2019), pp. 324-53.

10 Some examples: P. McDowell, The Women of Grub Street: Press, Politics, and Gender in The London Literary Marketplace 1678-1730 (Oxford 1998); C.E. Harline, Pamphlets, Printing and Political Culture in the Early Dutch Republic (Dordrecht etc. 1987); B. Capp, Astrology and the Popular Press: English Almanacs 1500-1800 (Ithaca 1979); L. Shepard, The History of Street Literature. The Story of Broadside Ballads, Chapbooks, Proclamations, News-sheets, Election Bills, Tracts, Pamphlets, Cocks, Catchpennies, and Other Ephemera (Newton Abbot 1973); R. Siegert, "The Greatest German Book Success of the Eighteenth Century: Rudolph Zacharias Becker's "Noth- und Hülfsbüchlein" (1788/1798) as the Prototype of Printed Volksaufklärung and its Dissemination in Europe', in: Crossing Borders, Crossing Culture: Popular Print in Europe, ed. M. Rospocher, J. Salman \& H. Salmi (Berlin/Boston 2019), pp. $245^{-6}$.

11 Some relevant exceptions are: A. Dutu, La circulation de l'imprimé dans le Sud-Est européen entre le XVIII e ${ }^{e}$ le XIX ${ }^{e}$ siècle, in: Chartier \& Lüsebrink, op. cit. (n. 3), pp. 165-170 and some chapters in: Atkinson \& Roud (eds.), op. cit. (n. 1: 2019). 


\section{Models, Questions, Approaches and Sources}

One of the conclusions to be drawn from the studies already undertaken is that distribution not only reveals the geographical and social range of popular print, but also the meanings attributed to its content. In other words, the social position, ethnicity, gender, as well as the practices of itinerants are manifestations of the literary, social and economic meaning and value of their stock. The books sold by a well-known, local pedlar with a solid reputation, were probably considered more reliable than the books offered by a foreign pedlar who only visited the city just once. In the volume Not dead things Harms, Raymond and Salman formulated this as follows: 'distribution was not merely a mechanical phenomenon but also a process laden with meanings that were experienced by the movers and recipients of books. ${ }^{12}$ They proposed a shift from distribution to dissemination ${ }^{13}$ because this makes the field more inclusive and meaningful. In the case of newspapers and news sheets, for instance, not only the mobility of the physical (paper) object should be reconstructed, but also the trans-European translations, adaptations and recycling of the news itself. Distribution as such, does not cover the myriad interactions between oral, scribal or printed corantos (newspapers). ${ }^{14}$ This multimediality equally defines the world of the early modern ballad. ${ }^{15}$ Singing and performing can indeed be considered as a form of disseminating news and entertainment in the streets without a print being a necessary medium. ${ }^{16}$ Dissemination makes us also aware of modes of distribution that are devoid of commercial aims. Distributors of seasonal items such as printed New Year's gifts handed out their goods for free, but expected a small gift. ${ }^{17}$

A similar conceptual innovation was proposed by Bellingradt and Salman in the volume Books in Motion. They suggested that Robert Darnton's famous

12 Harms, Raymond \& Salman (eds.), op. cit. (n. 5), p. 4.

13 Harms, Raymond \& Salman (eds.), op. cit. (n. 5), p. 10.

14 Harms, Raymond \& Salman (eds.), op. cit. (n. 5), pp. 7, p. 23. See also J. Raymond, 'International News and the Seventeenth-Century English Newspaper', Harms, Raymond \& Salman (eds.), op. cit. (n. 5), pp. 229-51;J. Koopmans, 'Storehouses of News: The Meaning of Early Modern News Periodicals in Western Europe', Harms, Raymond \& Salman (eds.), op. cit. (n. 5), pp. $25^{2-73}$.

15 See U. McIlvenna, S. Brandtzæg \& J. Gomis, 'Singing the News of Punishment: The Execution Ballad in Europe, 1550-19oo', this issue, pp. 123-159; S. Dall'Aglio, B. Richardson \& M. Rospocher (eds.), Voices and Texts in Early Modern Italian Society (Oxon/New York 2017).

16 See about the impact of street singers and performers Street Singers in Renaissance Europe, ed. L. Degl'Innocenti \& M. Rospocher, special issue of Renaissance Studies, 33 (2019).

17 Salman, op. cit. (n. 5), pp. 9o-2. 
model of production, distribution and consumption should be augmented with the more activating and interconnective concepts of spatiality, sociality and materiality. These concepts can open up new ways of studying the dissemination of popular print as well. Spatiality draws attention to, aside from distribution routes, the social distance between pedlars and local booksellers, and between street sellers and their clients. Were the relations between booksellers and pedlars always strained? We know for instance that pedlars often worked closely together with booksellers and that they sometimes were even family. What do we know about long-term (and perhaps personal) relations between pedlars and (rural) customers? How common was buying on credit? Were moral values such as trust and loyalty applicable here? Did language, religious convictions or social status thwart (or foster) trade relations? The concept 'sociality' is useful to highlight the less obvious and often neglected chains in the distribution networks such as shippers, smugglers, entrepôt keepers, wagoners, binders, priests, schoolmasters (selling schoolbooks in class), neighbours and family members (exchanging newspapers and books). ${ }^{18}$ To take another example, in eighteenth-century Venice priests commissioned works or sold books themselves via book stalls. ${ }^{19}$

In the following I would like to systematically discuss a number of fundamental issues, questions, approaches and sources. I will take the conceptual notions discussed here into account. The starting point is not only a broad European scope but also an extended time span. This is in order to measure the impact of changing conditions in the book industry (technological as well as organisational) as well as more general social-economic, political and religious reforms. Only then we can determine how (in)congruent European dissemination-infrastructures around popular print were.

\section{Vendors of Popular Print}

An important precondition for comparative research into the distribution and dissemination of popular print is an attempt to define, categorise and map the different book sellers in this field. In general, three major groups can be identified: regular (official) booksellers and book shops, institutional booksellers and non-sedentary, itinerant booksellers, often known as pedlars. Of course, this division was, in the historical reality, not strictly demarcated; for instance, the same people could perform different roles. Also stall-holders could be

18 D. Bellingradt, P. Nelles \& J. Salman (eds.), Books in Motion in Early Modern Europe: Beyond Production, Circulation and Consumption (New York 2017), pp. 1-11.

19 L. Carnelos, 'L'arte degli stampatori e dei librai e la contraffazione nella Venezia del Settecento', in: Il libro. Editoria e pratiche di lettura nel Settecento, ed. L. Braida \& S. Tatti (Rome 2016), pp. 145-56. 
somewhere between regular and irregular. Considering the first group: we tend to forget that cheap books, pamphlets, almanacs, penny prints and the like were also lucrative wares for established booksellers. In some cases these shops were even specialised in a specific item, such as pamphlet shops in London. ${ }^{20}$ The 'Ballad Partners', a syndicate within the Stationers' Company, comprised a network of stationers, printers and booksellers, which dominated the sale of ballads in London from the late-sixteenth century onwards. Eventually they extended their supply with 'small godly books' and 'small merry books'. ${ }^{21}$ Another group of bookshops specialised in popular books in general, with a special focus on the unwieldy category of chapbooks. On London Bridge from the 166os onwards, Charles Tias and later Thomas Passinger sold cheap 'small merry', 'small godly' books and chapbooks, but also primers, hornbooks, ballads and playing cards. From their shop they also supplied pedlars. ${ }^{22}$ In France a similar strategy was applied by Jean and Nicolas Oudot in Troyes, who offered 'livres bleu' (the 'Bibliothèque Bleue'). ${ }^{23}$ In the Dutch Republic and the Southern Netherlands penny prints were distributed via itinerants as well as via an advanced network of bookseller/wholesalers and 'resellers'. ${ }^{24}$ In Italy the Remondini publishing house (from 1657 onwards) cannot just be considered a publishing house specialised in cheap print, but prints and other kinds of cheap booklets and chapbooks were still an important publishing strategy. Interesting is this context is also that they struggled for a long time to get formal recognition as guild members. ${ }^{25}$

In large metropoles such as London ('Grubstreet') and Amsterdam ('Devil's Corner') certain areas in the city where notorious for the concentration of hack writers, obscure theatres and the sale of cheap print. In the Amsterdam Devil's Corner an ill-reputed bookseller such as Jacobus van Egmont could even profile himself as a seller of 'pulp' or 'pedlars literature'. ${ }^{26}$ The sale of cheap books was not the exclusive right of these specialists, however. Also book shops in the

\footnotetext{
$20 \quad$ McDowell, op. cit. (n. 10), pp. 55-7, pp. 101-2.

21 Watt, art. cit. (n. 7), p. 64; Spufford, op. cit. (n. 7:1981), pp. 83-110.

22 Spufford, op. cit. (n. 7:1981), pp. 91-101; J. Raven, The Business of Books: Booksellers and the English Book Trade 1450-1850 (New Haven 2007), p. 84.

23 R. Mandrou, De la culture populaire aux ıze et 18e siècles: La Bibliothèque Bleue de Troyes (Paris 1964).

24 N. Boerma, A. Borms, A.Thijs \& J. Thijssen, Kinderprenten, volksprenten, centsprenten, schoolprenten: Populaire grafiek in de Nederlanden 1650-1950 (Nijmegen 2014), pp. 78-89.

25 M. Infelise, I Remondini: Stampa e industria nel Veneto del Settecento (Bassano 1990). See also A.W.A. Boschloo, The Prints of the Remondinis: An Attempt to Reconstruct an Eighteenth-Century World of Pictures (Amsterdam 1998). See also L. Carnelos, 'Popular Print under the Press: Strategies, Practices and Materials', this issue, pp. 8-35.

26 J. Salman, 'From Grub Street to the Devil's Corner: The Literary Underground in Eighteenth Century London and Amsterdam', Quaerendo, 42 (2012), pp. 134-57.
} 
upper segment of the market, profited from the sale of sought-after items such as pamphlets, jestbooks, prose novels, newspapers and almanacs. ${ }^{27}$

The second group, institutional booksellers, comprised guilds, mail carriers, civil servants, schoolmasters, but also circulating libraries and commercial libraries. They took a (small) share in the sale of almanacs, newspapers and schoolbooks. ${ }^{28}$ Essential for the dissemination of popular print however was the third group: the itinerant book sellers. But soon as we start to frame these itinerants book sellers, we encounter conceptual confusion. This group is extremely multifaceted and therefore hard to define. Are we talking about the same thing, when we refer to a pedlar, hawker, chapman, street vendor or a colporteur? Fontaine ostentatiously stated that the pedlar did not exist. In her view the pedlar represented a very heterogeneous group of travelling merchants. ${ }^{29}$ In the context of our Europe-wide scope I also am in favour of a broad definition and that is the reason I use the term 'itinerant book sellers' from which designation one wouldn't exclude itinerants who sold non-book items such as broadsides, penny prints and pamphlets.

Despite this semantic pragmatism I do consider it useful, in view of a comparative approach, to categorise this heterogenous group of itinerants. The main researchers in the field have applied different methods to achieve this. They either divide the pedlars on the basis of wealth (Spufford) or on the basis of credit (Fontaine, Van Damme; Milano) or on the basis of trade practices (Salman). In the wealth system Spufford makes a distinction looking at property and goods, based on sources like wills and probate inventories. It is clear that poor pedlars without any property are excluded here. ${ }^{30}$ Using the credit system Van Damme made a distinction between the marginal pedlar, regular pedlar and the merchant-pedlar. Alternatively, trade practices can shape the categorisation. This leads to the following groups: the occasional pedlar; the pedlar with printed matter and other goods; the pedlar with printed matter exclusively; the pedlar selling specialist printed matter. ${ }^{31}$

Of course, all these categorisations are somewhat artificial and do not always represent reality, but they do have an analytic value. With the last

27 See for almanac sellers R. Chartier \& H.-J. Lüsebrink (eds.), Colportage et lecture populaire: Imprimés de large circulation en Europe $X V I^{e}-X I X^{e}$ siècles (Paris 1996); B. Capp, Astrology and the Popular Press: English Almanacs 1500-1800 (London-Boston 1979); J. Salman, Populair drukwerk in de Gouden Eeuw: De almanak als lectuur en handelswaar (Zutphen 1999).

28 Salman, op. cit. (n. 5), p. 190.

29 Fontaine, op. cit. (n. 2), p. 202; Salman, op. cit. (n. 5), p. 2.

$30 \quad$ Spufford, op. cit. (n. 2), pp. 43-67.

31 Salman, op. cit. (n. 5), pp. 119-20. 
four categories we can make several subdivisions (urban vs rural, regular vs irregular). What is more, several categories partly coincide with the credit classification of Van Damme: regular pedlars and pedlars selling printed matter and other goods; marginal traders and occasional traders and the specialists; merchant-pedlars and pedlars selling printed matter exclusively (with a bookstall in this case). In a substantial comparative project, this categorization would be a good framework.

\section{Urban versus Rural Dissemination}

One of the main issues in this field is what the differences are between popular print traded in the city and the countryside. Many scholars have assumed a correlation between itinerant trade, the dissemination of print, the degree of urbanisation and the presence of a good infrastructure. ${ }^{32}$ Illustrative in this context is the debate between Roger Chartier and Margaret Spufford, in which Chartier asserted that French pedlars started to distribute chapbooks in rural areas no earlier than the eighteenth century. Spufford on the other hand, was convinced that these itinerants were already supplying the countryside a century earlier. She attributed this blind spot to an overrepresentation of obvious urban sources, such as protests of bookshops owners. The fact that the rural areas remained silent, does not mean pedlars were absent, according to Spufford. It only means we haven't yet found these rare sources. ${ }^{33}$ Subsequent research has proven Spufford right. ${ }^{34}$ Jason Peacey has argued that after the English Civil War pedlars started to distribute controversial news items such as pamphlets and newspapers, not only in London, but also in the provinces. ${ }^{35}$ The growing legislation in England from the 1670 s onwards also signals a rise of trade activities in city as well as the countryside. The 1697 Act for Licensing Hawkers and Pedlars confirmed that at that moment a network of pedlars was already present covering the whole country. ${ }^{36}$ In addition to this kind of research John Hinks and Maureen Bell have done a survey on the basis of the British Book Trade Index-database. They made a useful large scale and long-term analysis of the spread of booksellers and printers in London and

\footnotetext{
32 Illustrative are the urbanisation levels even around 180o: the Netherlands: $37 \%$; England: 30\%; Germany: 17\%; France: 12\%. J. Kloek \& W. Mijnhardt, 180o: Blauwdrukken voor een samenleving (Den Haag 2001), p. 38.

33 R. Chartier, The Cultural Use of Print in Early Modern France. Translated by Lydia G. Cochrane. (Princeton 1987), pp. 176-7; Spufford, art. cit. (n. 7), p. 15 .

34 Watt, op. cit. (n. 7); Watt, art. cit. (n. 1).

35 J. Peacey, "Wandering with Pamphlets". The Infrastructure of News Circulation in Civil War England', in: Harms, Raymond \& Salman (eds.), op. cit. (n. 5), pp. 113-14.

36 Salman, op. cit. (n. 5), pp 100-1.
} 
the provinces. This helps to determine how widespread the dissemination of popular print could have been. ${ }^{37}$

In the Dutch Republic the level of urbanisation was relatively high in the early modern period. Combined with a high literacy rate and an advanced system of waterways and barges, this made circumstance extremely favourable for the dissemination of popular print. ${ }^{38}$ In order to describe the wide spread of booksellers over the country, Rasterhoff coined the term 'polycentric book industry'. This entails that monopolies were absent and production and distribution networks dense. ${ }^{39}$ The assumption however that itinerant trade would be absent in such a urbanised area was false. Also in cities, due to the low attendance rate of bookshops probably, street sellers were an essential extension of the local bookshops. ${ }^{40}$ And what is more, cities provided permits to local pedlars not only to sell print in the city itself, but also in the surrounding countryside. ${ }^{41}$

These examples make clear that a European wide scope on distribution should take into account the level of urbanisation, literacy, infrastructure, but also more specific geographical circumstances (mountains, flat land, waterways, means of transport, sea harbours and so on). Furthermore, it can be fruitful to look at regions and places instead of 'nations' and to compare Catholic areas with Protestant regions. And within these comparisons we should keep an eye on totally different circumstances as well. What about the role of post services in a specific country for instance, and the infrastructure around fairs and markets? ${ }^{42}$ Newspapers for example, were often sent via regular post services. Michael Harris asserted that around the 176 os over 35,000 newspapers were sent every week from London to the provinces. ${ }^{43}$ It should not be forgot-

37 M. Bell \& J. Hinks, 'The English Provincial Book Trade: Evidence from the British Book Trade Index', in: The Cambridge History of the Book in Britain, vol. 5: 1695-183o, ed. M.F. Suarez and M.L. Turner (Cambridge 2009), pp. 335-51.

38 The Dutch Republic counted 61 cities in 1675 , most of them (38) in the province of Holland. Harms, Raymond \& Salman (eds.), op. cit. (n. 5), p. 15; J. de Vries, Barges and Capitalism: Passengers Transportation in the Dutch Economy (1632-1839) (Utrecht 1981), pp. 13-17.

39 C. Rasterhoff, Painting and Publishing as Cultural Industries: The Fabric of Creativity in the Dutch Republic, 1580-1800 (Amsterdam 2016).

$40 \quad$ Salman, op. cit. (n. 5), pp. 244-8.

41 Salman, op. cit. (n. 5), p. 187.

42 In England and Wales The City and Country Chapmans Almanack for the Year our Lord 1685 (London [1684]) was an important help for itinerant distribution. Capp, op. cit. (n. 27), p. 355 .

43 M. Harris, London Newspapers in the Age of Walpole (London 1987), pp. 40-6. 


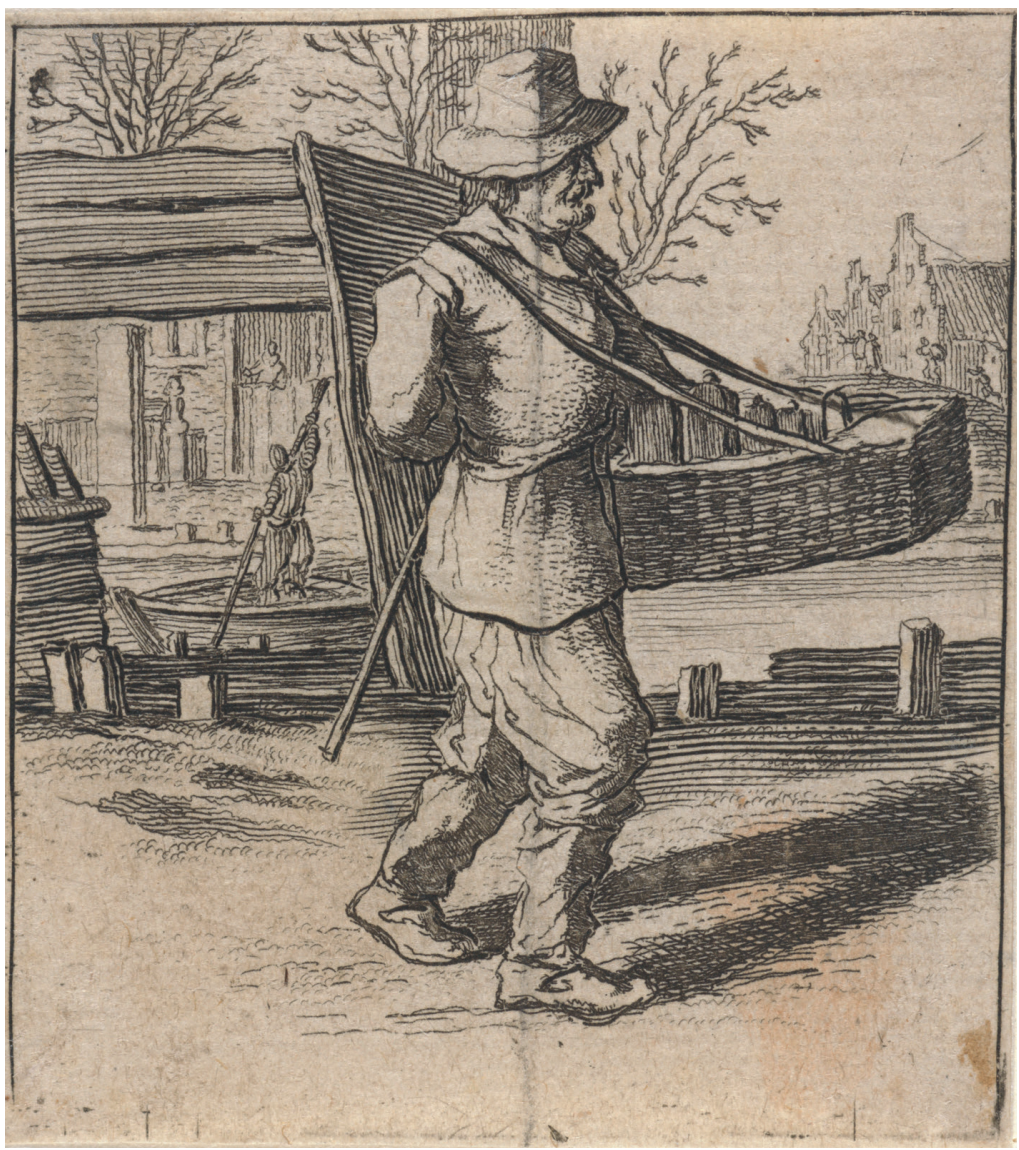

FIGURE 1 Gillis van Scheyndel (I), Dutch pedlar in a small village

Etching. Published by Johannes Pietersz. Berendrecht, Haarlem, between $1618-1638$

RIJKSMUSEUM AMSTERDAM, RP-P-OB-15.091

ten that the means of transport were very different in the sixteenth century as compared to the second half of the nineteenth century. ${ }^{44}$

\section{Range of Distribution Networks}

Connected to this urban-rural divide is the question what the radius was of itinerant book sellers and what the main differences are between local street sellers and long-distance pedlars and hawkers (such as social background,

44 About popular print and the rise of the railway see F. Tancini, 'The Railway Library and Other Literary Rubbish that Travels by the Rail', in: Rospocher et al., op. cit. (n. 10), pp. 71-8. 
collaboration, goods, trade practices). A major caveat in this kind of research is that certainly not all pedlars I can trace carried books. In many cases we do not even know if they did. The so-called 'Teuten' or 'Tödden' (around 6,ooo in 1811) had a large area of distribution (south-east of the Dutch Republic, the northern Southern Netherlands, Western part of Germany), but did not sell printed wares, but mainly textiles. ${ }^{45}$ Laurence Fontaine discovered three European networks in the 18th century but also in this case not all of these groups sold books. ${ }^{46}$ A group of long-distance pedlars that traded in print for sure were the Tesini pedlars. They distributed millions of Remondini prints (variously devotional, decorative and historical) from the Tesino valley in the north of Italy all over Europe. Several Italian scholars have done ground-breaking work in reconstructing this impressive trans-European network. ${ }^{47}$ Often these longdistance pedlars lived together in the same area or in the same villages. In the French Vosges one third of the 15 o households of the village Chamagne were long-distance pedlars, distributing (usually on foot) religious as well as secular material (Epinal prints, 'livres bleus' and ballads) throughout France and parts of current Belgium. ${ }^{48}$ Another feature of the long-distance pedlars was that they usually travelled in groups (which was safer), had fixed routes, regular customers and strategic warehouses and visited the same taverns. Finally, one of the preconditions to survive was a system of mutual trust. ${ }^{49}$

\section{Trade Regulations and Economic Impact}

One of the excitements of a transnational comparison is that it shed light on the questions of when, why and how commercial and legal regulation of regular and itinerant trade took place in different countries or regions. Regulation had consequences for the marketing, content and materiality of popular genres among other things. Within the book industry itself, it is relevant to know to what extent itinerant traders competed, quarrelled or collaborated

45 Salman, op. cit. (n. 5), pp. 186-7; J. Lucassen, Naar de kusten van de Noordzee: Trekarbeid in Europees perspectief (Gouda 1984), pp. 111-19, pp. 144-5, pp. 194-5. There is not one clear etymological explanation for the origin of the words teuten and tödden.

46 Fontaine, op. cit. (n. 2), p. 50-72; M.I. Casas Delgado, Ecos de modernidady paneuropeísmo en la literatura de cordel española (Sevilla 2017), p. 187.

47 A. Milano, "Selling Prints for the Remondini"': Italian Pedlars Travelling Through Europe During the Eighteenth Century', in: Harms, Raymond \& Salman (eds.), op. cit. (n. 5), pp. 75-96. About the Tesini pedlars see also the seminal work of E. Fietta. Con la cassela in spalla: gli ambulanti di Tesino (Ivrea 1987). About the Remondini see L. Carnelos, I libri da risma: Catalogo delle edizioni Remondini a larga diffusione (1650-1850) (Milan 2008).

48 D. Hopkin, 'Ballads and Broadsides in France', in: Atkinson \& Roud (eds.), op. cit. (n. 1), pp. $71-2$.

49 Salman, op. cit. (n. 5), p. 187. 
with established booksellers in their own country or abroad. One way to go about this is to compare the rise of local and national institutions - such as guilds and censorship offices - which aimed to regulate, control and professionalise the book trade. Ordinances, statutes and petitions should then inform us about the details and practices of these institutions. They do not always send out a message of conflict and animosity, however. For sixteenth century Venice, Salzberg observed a close collaboration between urban street sellers and established booksellers. ${ }^{50}$ In eighteenth-century Spain and Portugal, on the other hand, these sources clearly reveal permanent tensions between guilds, booksellers and peddlers ('volanteiros' in Portuguese) about the control of the lucrative market for cheap print (broadsheets). ${ }^{51}$ What were the criteria to accept guild members and did they shift over time? We know, for instance, that over time Dutch guilds accepted pedlars as (semi) members because they believed they could control street trade better. ${ }^{52}$ In Venice poor members of the guild and old compositors were allowed to sell books on the street on holy days, when all the other shops were closed. It was a way to help them to earn a living. ${ }^{53}$

In other areas pedlars established their own unions and guilds to protect their interests. Rather unique in this respect is the high level of organisation in Scotland. John Morris identified five different pedlar organisations of which the oldest was the 'Fraternity of Chapmen in the Three Lothians' (1530). The Chapman Court of Fife (meeting at Kilconquhar) was founded in 1706 and the Fife Chapman Society (meeting at Cupar) in 1705; the Chapmen of Perthshire and the Fraternity of Chapmen in Stirlingshire in 1726.54

Were authorities willing to co-operate with organisations of established booksellers to control street trade and popular print? In England the situation was unique. The Stationers' Company, founded in 1557, worked in the service of the national authorities and exercised strong control on book production and distribution. After the lapse of the Printing Act in 1695 this centralised infrastructure changed radically, with a strong growth of the provincial trade

$5^{\circ} \quad$ Salzberg, op. cit. (n. 9), pp. 73-97.

51 Casas Delgado, op. cit. (n. 46), p. 165.

$5^{2}$ Salman, op. cit. (n. 5), p. 188.

53 L. Carnelos 'Words on the Street: Selling Small Printed "Things" in 16th- and 17th-Century Venice', in: News Networks in Early Modern Europe, ed. N. Moxham and J. Raymond (Leiden and Boston 2016), pp. 739-55.

54 J. Morris, 'The Scottish Chapman', in: Fairs, Markets and the Itinerant Book Trade, ed. R. Myers, M. Harris \& G. Mandelbrote (New Castle 2007), pp. 159-86. Viviene Dunston discovered on the basis of the register of the Fife Chapman Society that between 1764-1799 51 chapmen were admitted to the society: Dunston, art. cit. (n. 7), p. 48. 
as one of the main consequences. Despite the fact that more cheap books and pamphlets became available in the countryside, the 1697 Act for Licensing Pedlars and Hawkers enforced a restrictive policy towards itinerant trade. ${ }^{55}$ Local authorities were not always willing, however, to ban street trade from their cities. It could have economic and social benefits. ${ }^{56}$ This makes us aware of the fact that we are often misled by the normative and corrective sources and therefore postulate that all pedlars were illegal and always worked against the law. Many of them had permits and licenses and were surely not part of an underground and illegal distribution system.

One of the instruments that had both a controlling and legalising effect, was granting monopolies to a sole group of pedlars and sellers of print. In Spain, Portugal, Italy and England the so-called brotherhoods of the blind, supported and controlled by church and state, acquired exclusive rights to produce and disseminate cheap print such as songs. In eighteenth-century Madrid for instance the 'Nuestra Señora de la Presentación y Ánimas del Purgatorio' received the exclusive right to produce and disseminate 'relaciones de reos. ${ }^{57}$ In Italy these brotherhoods were present in many cities: Genoa, Venice, Florence, Padua, Milan, Bologna, Rome, Siena and Palermo. ${ }^{58}$ Although these brotherhoods were present in many other countries as well, they were not always involved in the sale of print. ${ }^{59}$ It would be interesting to see how and why these differences emerged. Alongside general restrictions for itinerant traders, other regulations could be enacted prohibiting or licensing specific forms of popular print, as happened in Venice in the 155 os and 1560 . ${ }^{60}$

In the context of regulation and control, it is not only commercial motives and organisations that are of interest here, but also political and social

55 Spufford, op. cit. (n. 7), p. 14; J. Feather, 'The History of the English Provincial Book Trade: A Research Agenda', in: Light on the Book Trade: Essays in Honour of Peter Isaac, eds. B. McKay, J. Hinks \& M. Bell (New Castle 2004), pp. 1-7.

56 Salman, op. cit. (n. 5), pp. 249-50.

57 J-F. Botrel \& J. Gomis, "Literatura de cordel" from a Transnational Perspective: New Horizons for an Old Field of Study', in: Rospocher, Salman \& Salmi (eds.), op. cit. (n. 10), p. 140. See also L. Carnelos, 'Street Voices: The Role of Blind Performers in Early Modern Italy, Italian Studies, 71 (2016), pp. 184-96; J. Gomis, 'Pious voices: Blind Spanish Prayer Singers', Renaissance Studies, 33 (2019), pp. 42-63; Casas Delgado, op. cit. (n. 49), pp. 163-4; F. Guedes, Os Livreiros em Portugal e as suas associações desde o século XV até aos nossos dias, (Lisbon 2005); J.-F. Botrel, 'Les aveugles, colporteurs d'imprimés en Espagne, I', Mélanges de la Casa de Velázquez, 9 (1973), pp. 417-82; J.-F. Botrel, 'Les aveugles, colporteurs d'imprimés en Espagne, II', Mélanges de la Casa de Velázquez, 10 (1974), pp. 233-71. See also McIlvenna, Brandtzæg \& Gomis, art. cit. (n. 15).

58 Carnelos, art. cit. (n. 57).

59 Botrel \& Gomis, art. cit. (n. 57), p. 140.

6o Salzberg, op. cit. (n. 9), pp. 135-142. 


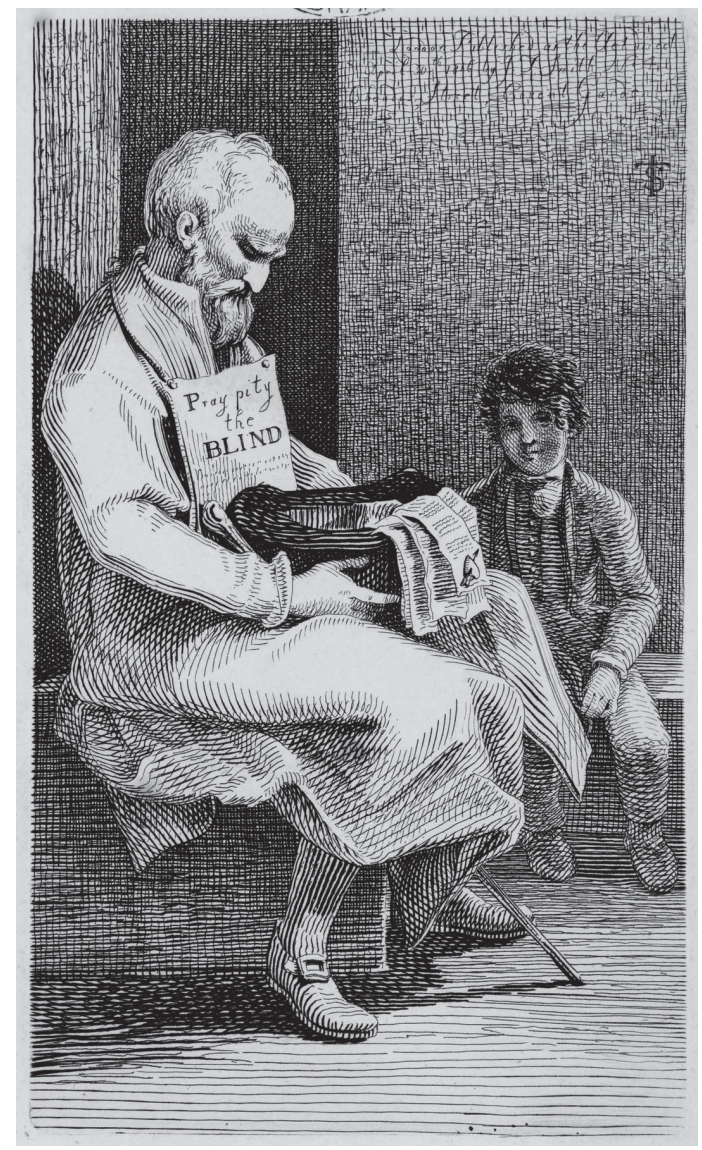

FIGURE 2 J.T. Smith, Blind street performer and a boy selling ballads

Etching. Published by J.T. Smith, London, 1815 BRITISH LIBRARY, LONDON, BL 134.D.6

considerations. In sixteenth-century Venice and Amsterdam peddling and ballad selling was associated with reformed religion and therefore distrusted. ${ }^{61}$ Governments issued laws to prevent itinerant traders selling pamphlets on streets because they could arouse religious, social and political uproar. ${ }^{62}$

61 Salzberg, 'Print Peddling and Urban Culture in Renaissance Italy', in: Harms, Raymond \& Salman (eds.), op. cit. (n. 5), pp. 33-51; J. Salman, 'Frail Echoes of Singing in the Streets: Tracing Ballad Sellers and Their Reputation in the Low Countries', Renaissance Studies, 33 (2019), pp. 119-35; F. Deen, Publiek debat en propaganda in Amsterdam tijdens de Nederlandse Opstand: Amsterdam 'Moorddam' (1566-1578) (Amsterdam 2015), pp. 103-36.

62 Harms, Raymond \& Salman (eds.), op. cit. (n. 5), p. 10. 
A well-known English manifestation of this is the Act of Common Council from 1643 that was directed against:

[...] a multitude of vagrant persons, men, women and children, which after manner of hawkers, doe openly cry about the streetes, pamphlets, and other bookes, and under colour of thereof are found to disperse all sorts of dangerous Libels, to the intolerable dishonour of the Kings Maiesty, and of the high Court of Parliament, and the whole Government of this Realme, and this City in particular. ${ }^{63}$

From the literature on this topic we can observe some major turning points in the organisation of regulation in European countries and regions, be it for economic or political reasons. In Italy, and more specifically in Venice, we see an accumulation of restrictions towards selling print without permission (including pedlars) from the $1560{ }^{64}{ }^{6}$ Both in England and the Dutch Republic regulations towards pedlars and street sellers became stricter from the 166os. Instances like this, can help to determine more general patterns in the growing economic or political impact of specific popular genres. It is without doubt that the French Revolution caused a landslide within the regulation of the book industry. In the Netherlands, for instance, not only the French term 'colporteur' was introduced, but the itinerant book trade was to a certain extend institutionalised. Directly after the French revolution the Dutch booksellers guilds where officially abolished (1798), and the book trade was devoid of any form of regulation. In 1805 this was partly solved with the introduction of patents (legal permits) to sell books and other products. From that moment on (some) colporteurs obtained a more regular status. Pedlars were for instance commissioned by bible societies to sell bibles in the countryside and publishers began to recruit colporteurs that went from door to door with subscription lists and prospectuses. $\ln 1868$ the book pedlars even established their own journal, De Kolporteur or the BookPedlar. ${ }^{65}$ The implication could be that pop-

63 Quoted in D. Freist, Governed by Opinion: Politics, Religion and the Dynamics of Communication in Stuart London, 1637-1645 (London 1997), pp. 112-13.

64 But also founding the local booksellers' guild in Venice in 1549 was a sign of increasing control: Salzberg, op. cit. (n. 9), pp. 144-7.

65 Salman, op. cit. (n. 5), pp. 15, pp. 31-2; C.F. Gronemeijer, Gedenkboek van het Nederlandsch Bijbelgenootschap, 1814-1914 (Amsterdam 1914); L. Kuitert, 'Grote boeken voor de kleine man: Colportage in Nederland in de negentiende eeuw', De negentiende eeuw, 20 (1996) pp. 93-105; L. Kuitert, 'De Kolporteur (1868-1889): Vakblad voor een gefrustreerde beroepsgroep', De Boekenwereld (Themanummer: 'Geboekt in jaargangen: anderhalve eeuw boekentijdschriften in Nederland'), 10 (1994), pp. 36-40. 
ular print gained more respectability. ${ }^{66}$ In France on the contrary, the repression of pedlars became fiercer after 1850 , with the imposition of more severe censorship laws. ${ }^{67}$

As already said, there can be no doubts anymore about the significance of itinerant book trade for the distribution of popular print. But this notion also raises questions about the economic impact of pedlars in general. Jan de Vries, a renowned economic historian, has asserted that retail shops and pedlars in the period 1650-1750 became an innovative force in the old market system and caused a greater supply of goods. ${ }^{68}$ How does this translate to the activities and goods of pedlars who carried print? Is it possible the estimate the market share of itinerants in distributing popular print in Europe? And what about the gendered nature of the division of tasks? ${ }^{69}$ Do we encounter the same female dominance in the production and dissemination of printed political news in other European cities, as occurred in London in the early eighteenth century? ${ }^{70}$ Indirectly, the economic power of pedlars has become visible due to established booksellers who recurrently accused street sellers of being unfair competitors. Pedlars would sell mainly foreign books and therefore spoiled the domestic market. What is more, they spread diseases and disseminated heterodox ideas. ${ }^{71}$ In reverse, pedlars time and again (via petitions etc.) stressed the economic benefits of their trade for the cities (taxes, licenses) and for their citizens (especially those with low incomes). They also claimed that they supplied people in rural areas with 'respectable' books. They fiercely opposed the suggestion that they were equal to vagabonds and beggars.

66 For Germany in the nineteenth century see: G. Scheidt, Der Kolportagebuchhandel (1869-1905): Eine systemtheoretische Rekonstruktion (Stuttgart 1994); H. Sarkowski, 'Der Buchvertrieb vor Tur zur Tur im 19. Jahrhundert', in: R. Wittmann \& B. Hack, Buchhandel und Literatur: Festschrift (Wiesbaden 1992).

67 J.- J. Darmon, Le colportage de librairie en France sous le Second Empire: Grands colporteurs et culture populaire (Paris 1972), p. 141.

68 J. de Vries, The Industrious Revolution: Consumer Behavior and the Household Economy, 1650 to the Present (Cambridge 2008), p. 169; Salman, op. cit. (n. 5), p. 112. See also H. Deceulaer, 'Dealing with Diversity. Pedlars in the Southern Netherlands in the Eighteenth Century', in: Buyers and Sellers. Retail Circuits and Practices in Medieval and Early Modern Europe, ed. B. Blondé et al. (Turnhout 2006), pp. 171-198.

69 See D. van de Heuvel, Women and Entrepreneurship: Female Traders in the Northern Netherlands, c. 1580-1815 (Amsterdam 2007).

$70 \quad$ Salman, op. cit. (n. 5), p. 255.

71 Salzberg, art. cit. (n. 61), p. 46. 


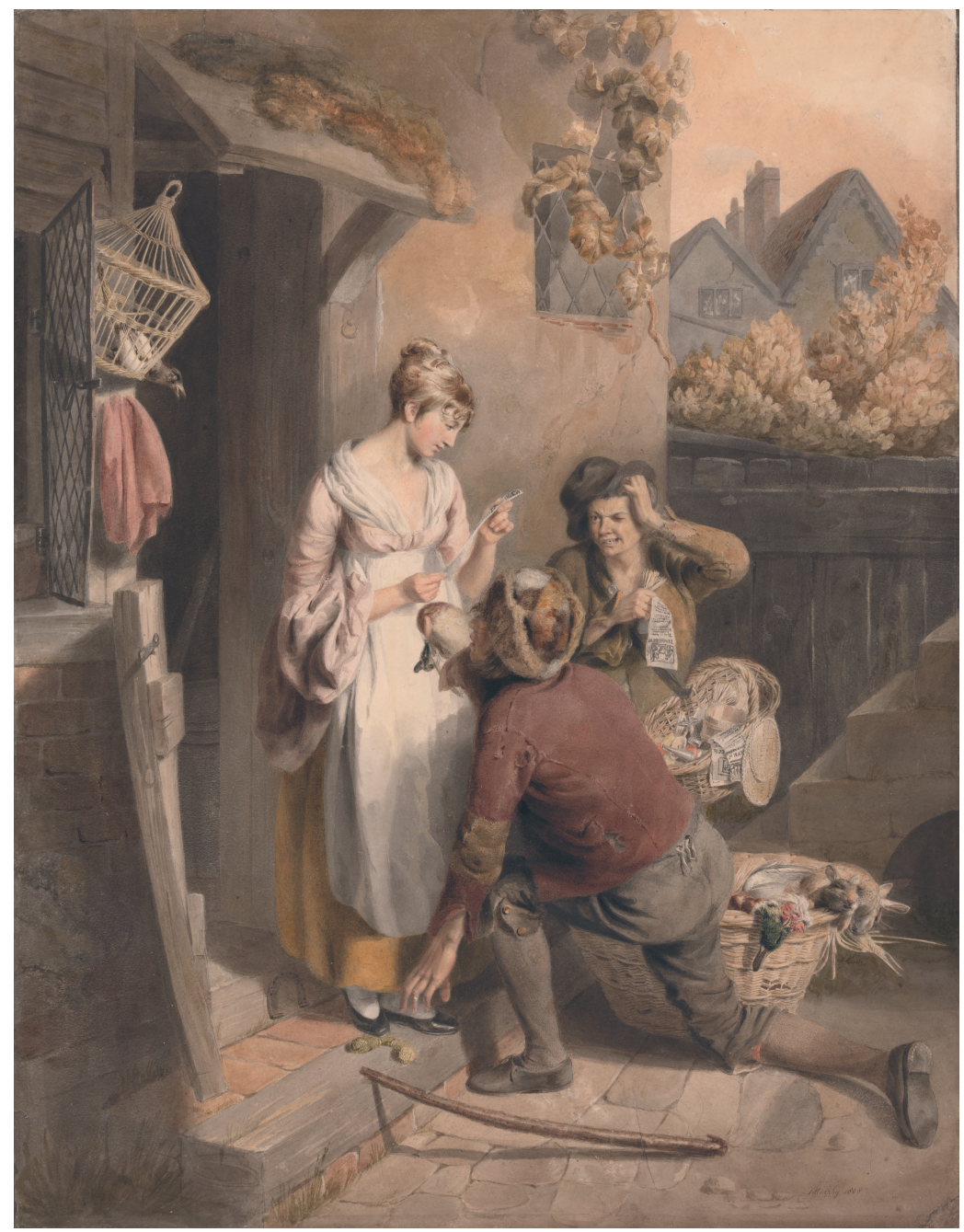

FIGURE 3 A clear representation of ill-reputed pedlars. One pedlar steels the purse of a young woman who is distracted while reading a slip song, offered by another pedlar

Thomas Heaphy (1775-1835), Inattention. Watercolor drawing, 1808 YALE CENTER FOR BRITISH ART, PAUL MELLON COLLECTION, B1975.3.175

\section{Trade Practices}

A comparative analysis of European trade practices would profit greatly from the categorisation introduced earlier: 1 . the occasional pedlar; 2 . the pedlar with printed matter and other goods; 3 . the pedlar with printed matter exclusively; 4 . the pedlar selling specialist printed matter. When we collect practices 
and conventions along these lines, the concepts I introduced earlier, spatiality, sociality and materiality, can help us to focus on the less obvious data. Furthermore, from earlier research we know that distribution practices are determined by the radius of the pedlar's routes, the level of collective organisation, the social background (class, sex, ethnicity, religion) of the street sellers, by topographical and climatic circumstances, by economic considerations and by type of print that was disseminated.

The issue of trade practices raises many questions, of which I will highlight only a few. How was collaboration between established and non-sedentary booksellers organised and perhaps formalised? How did long-term relations (credit, trust) differ from more ad hoc or flexible arrangements? Fascinating is also the role of pedlars as initiators of print productions and even as authors and composers. There are some instances of this in Italy, Spain, England and the Dutch Republic, but there must be many more. They wrote poems, songs, but sometimes also complete biographies. ${ }^{72}$ In nineteenth-century France, pedlars who produced canards sometimes carried their own woodblocks from place to place and ordered jobbing printers to produce new stock. ${ }^{73}$

One of the aspects of trade practices that we tend to forget are the (public) places and spots in cities and villages that pedlars and street sellers used to sell their wares. This is not only relevant to get insight in their commercial strategies, but also to know the impact of street trade on local culture. ${ }^{74}$ Ballads contributed to this local culture because before they were sold, they were often performed at public places. These performances differed in different European countries. In Germany the 'bänkelsängs' were sold with the help of coloured placards. They illustrated the story during the musical performance by the 'schilderänger. ${ }^{75}$ Practices were similar in the Dutch Republic and the Southern Netherlands. ${ }^{76}$ In the sources we encounter public places such as squares, bridges, streets, gatehouses, locks, barges, coffee houses and shops. Famous points of sale are Cripplegate, just north of London Bridge, the Dam square and the Buttermarket in Amsterdam. In the Venice of 1567, Salzberg counted a total of 64 fixed and mobile street sellers. The most popular points of sale where Piazza San Marco and Rialto bridge although eventually street

\footnotetext{
72 Carnelos, art. cit. (n. 9), pp. 324-53; Salzberg, op. cit. (n. 9), pp. 84-9; Gomis, art. cit. (n. 6o); Salman, op. cit. (n. 5), pp. 78-96; Watt, art. cit. (n. 7).

73 Hopkin, art. cit. (n. 51), pp. $75^{-6}$.

74 Salzberg, op. cit. (n. 9), pp. 58-62, pp. 161-2.

75 Casas Delgado, op. cit. (n. 49), p. 164.

76 W.L. Braekman, Hier heb ik weer wat nieuws in d'hand: marktliederen, rolzangers en volkse poëzie van weleer (Ghent 199o). See also McIlvenna, Brandtzæg \& Gomis, art. cit. (n. 15).
} 


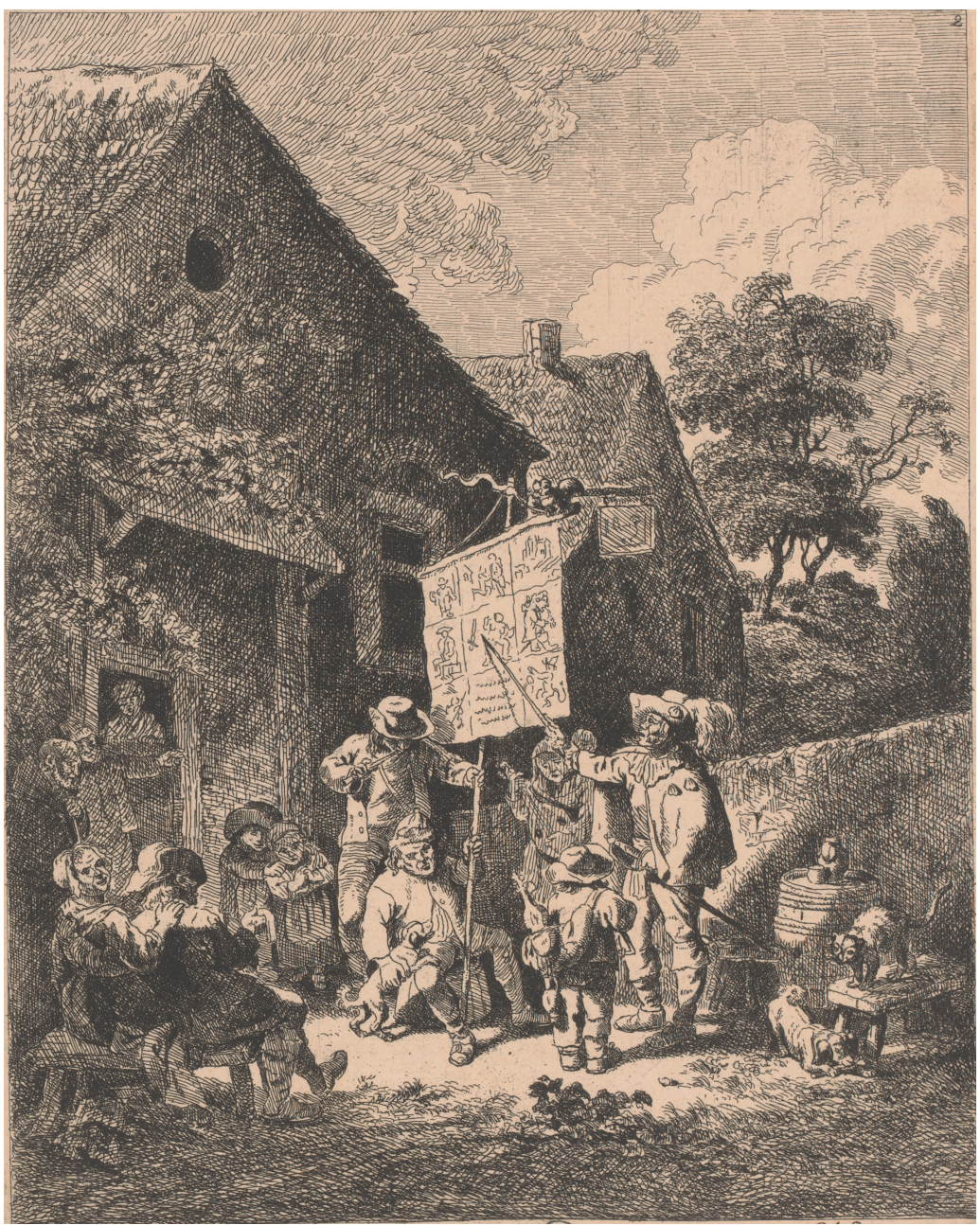

FIGURE 4 Friedrich Müller, 'Bänkelsängers', singing and selling songs, in front of an inn, with the help of coloured placards Etching. Published by Carl August Grossmann, n.p. , 1775 RIJKSMUSEUM AMSTERDAM RP-P-2002-224

sellers were present in every corner of the city. ${ }^{77}$ These strategies were not only determined by commercial considerations, but sometimes also simply by climatological circumstances. In Southern Europe chapbooks could more easily be offered in the open air, on the streets, bridges and squares, but in Northern Europe (Germany, England, Dutch Republic), due to the rain, pedlars

$77 \quad$ Salzberg, op. cit. (n. 9), pp. 51-8. 
more often had to resort to market stalls on fairs or other covered public places like arcades. ${ }^{78}$

Partly in connection to that, some popular genres where inherently seasonal and had to be sold at a specific day or a specific month of the year. This means that almanac sellers or distributors on new year prints/letters where often occasional pedlars (including children), doing other work in the rest of the year. Other genres were topical and needed to be sold within a few days. This goes for political pamphlets, but also execution ballads or dying speeches that had to be distributed close to the execution date. In Spain, for instance, the blind pedlars were keen to receive the official report before the execution. This gave them time to write and print the 'romance' and sell it when the event was still fresh. ${ }^{79}$

Keeping in mind the category of pedlars with print and other goods it is clear that in a European project, we should not focus on the street sale of printed goods exclusively. These itinerant vendors often combined print with the sale other cultural goods (toys for instance) and consumer goods (food, textiles, haberdashery, ribbons, soap, perfume, medicine, textile, toys, spectacles and even pasta!). ${ }^{80}$ Connected to this, pedlars where often combining trade with other jobs and activities, such as working in the fields, chimney sweeping, distributing letters, or begging. ${ }^{81}$

As referred to in the introduction, the concept of dissemination makes us aware of the many instances where print was handed out for free, aiming at specific communities for instance. Think about political propaganda (pamphlets, cartoons, libels) or educational material with edifying aims. ${ }^{82}$ A remarkable example of the latter is the well-organised itinerant distribution infrastructure around the German enlightened 'Noth- und Hülfsbüchlein' (1788-1798). ${ }^{83} \mathrm{In}$ this context it is worthwhile to pay especial attention to the dissemination of religious works, because these prints and booklets (aleluyas, sermon-books, prayer books, primers, catechisms, and so on) escaped the commercial circuit and were often distributed during certain rituals, or handed out for free to (for

\footnotetext{
78 Casas Delgado, op. cit. (n. 49), p. 172.

79 See McIlvenna, Brandtzæg \& Gomis, art. cit. (n. 15).

8o Salman, op. cit. (n. 5), pp. 82, pp. 193-7; Carnelos, art. cit. (n. 9), p. 340.

81 Salman, op. cit. (n. 5), pp. 188-9.

82 R. Harms, Pamfletten en publieke opinie. Massamedia in de zeventiende eeuw (Amsterdam 2011), pp. 67, pp. 212-13; Freist, op. cit. (n. 63), pp. 89-9o, p. 99;J. Thijssen, 'The Development and Distribution of the First Educational Print Series in the Netherlands, 1800-1820', in: Harms, Raymond \& Salman (eds.), op. cit. (n. 5) pp. 312-13.

83 Siegert, art. cit. (n. 10), pp. 245-63.
} 
example) church members or pupils of religious forms of education (such as Sunday schools). ${ }^{84}$

\section{Visual and Textual Representations}

The lack of administrative and juridical sources urges scholars sometimes to resort for their evidence to perhaps less objective and more challenging material, such as literary texts and images. And the reward is often great. These representations of pedlars could be a key to the social and cultural impact of itinerant book trade in different countries. ${ }^{85}$ In the case of England and the Dutch Republic negative and positive images were distributed equally, but in terms of reception there are interesting diverging patterns. ${ }^{86}$ These sources raise the intriguing question of how social reality and artistic representation interacted and shaped certain stereotypes. An interesting subfield in this context is the search for ethnic, social and religious stereotypes. Jews and 'gypsies' for instance, were often negatively portrayed in these representations. ${ }^{87}$

Paradoxically, the stereotype of the unfair competitor was omnipresent in European plays, novels, paintings and print, but from archival sources we know how established booksellers depended on street sellers. They were responsible for offering controversial material (pamphlets, songs) on the streets, but also to reach audiences that did not frequent a bookshop (in the countryside as well as in cities). By studying this material systematically we discover that booksellers in the Dutch Republic cultivated the negative images of pedlars in order

84 K. Peters, 'The Dissemination of Quaker Pamphlets in the 165os', in: Harms, Raymond \& Salman (eds.), op cit. (n. 5), pp. 213-28; L.J. Parr, 'Sunday School Libraries in Halifax and Huddersfield before Public Libraries', Library \& Information History, 25 (2009), pp. 50-67; J. Dane, De vrucht van Bijbelse opvoeding: Populaire leescultuur en opvoeding in protestantschristelijke gezinnen, circa 1880-1940 (Hilversum 1996), pp. 117-23; about cheap religious prints see Gomis \& Salman, art. cit. (n. 15).

85 See about visual representations: L. Buijnsters-Smets, Straatverkopers in beeld: tekeningen en prenten van Nederlandse kunstenaars circa 1540-1850 (Nijmegen 2012); A. Milano, Colporteurs: I venditori di stampe e libri e il loro pubblico (Milano 2019); S. Shesgreen, The Criers and Hawkers of London: Engravings and Drawings by Marcellus Laroon (Aldershot 1990); K. Bowen, 'Peddling in Texts and Images: The Dutch Visual Perspective', in: Harms, Raymond \& Salman (eds.), op. cit. (n. 5), pp. 153-180; M. Calaresu, 'Costumes and Customs in Print: Travel, Ethnography, and the Representation of Street-Sellers in Early Modern Italy', Harms, Raymond \& Salman (eds.), op. cit. (n. 5), pp. 181-209.

86 Salman, op. cit. (n. 5), pp. 92-6.

87 K. Chandler, Gypsies Hawkers and Other Travellers in the English South Midlands: An Anthology of References from Local Newspapers 1744-1911 (Oxford 2005); B. Naggar, Jewish Pedlars and Hawkers 1740-1940 (Camberley 1992). 
to enhance their negotiation position. Could it be that in countries where the book market was more regulated this phenomenon did not occur?

Aside from representations by others, we do have valuable instances of self-representation in the form of (a small number of) autobiographies of pedlars and ballad singers. They expose day-to-day practices and trade strategies, but also convey religious and social justifications and self-fashioning. ${ }^{88} \mathrm{~A}$ European inventory of relevant collections and repositories of egodocuments such as diaries, autobiographies, memoirs and perhaps even fictionalized lifestories could help us on the way. ${ }^{89}$

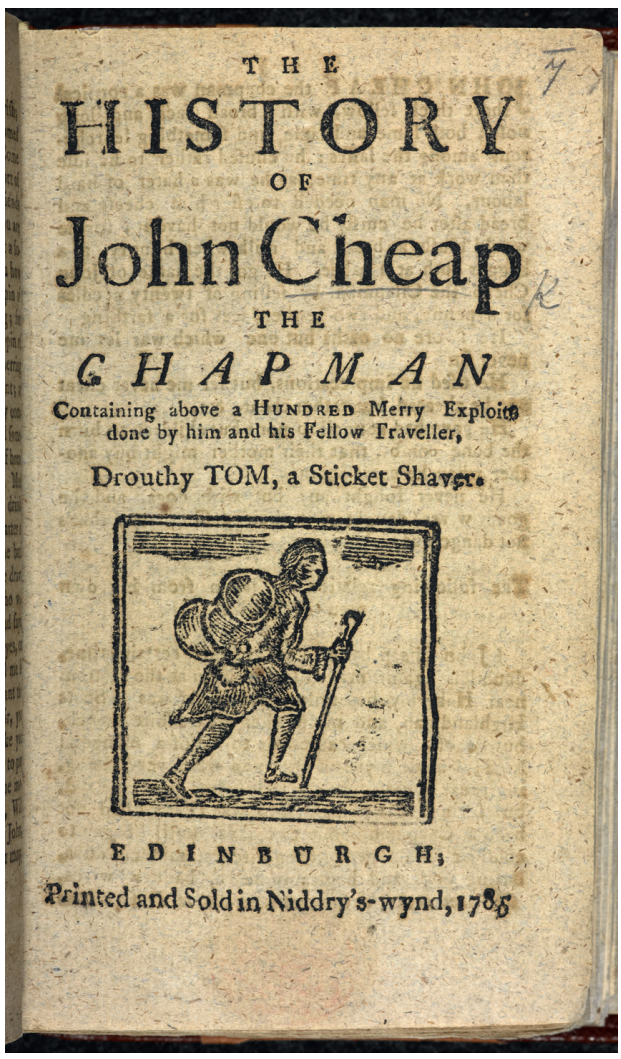

FIGURE 5

The fictionalised autobiography The History of John Cheap the Chapman reveals the life and work of the Scottish pedlar Dougal Graham Published in Edinburgh, Niddry's-wynd, 1785 . BRITISH LIBRARY, LONDON 12331.B.34

88 See McIlvenna, Brandtzæg \& Gomis, art. cit. (n. 15), referring to broadside ballads carrying images that represented the ways songs where disseminated.

89 J. Salman, 'Between Reality and Representation: The Image of the Pedlar in the 18th Century Dutch Republic', in: New Perspectives in Book History: Contributions from the Low Countries, ed. M. van Delft, Fr. de Glas \& J. Salman (Zutphen 2006), pp. 189-202; Hopkin, art. cit. (n. 51), p. 64 (about the street singer Françoise Chemin). 


\section{Perspectives for a Comparative Research Agenda}

This account of our current knowledge and survey of methodological approaches gives a sense not only of how much information we have, but how much we still do not know. The models proposed, the questions asked, the methods suggested, and the sources collected, are stepping stones to a more comprehensive European collaboration. I do think it highlights some useful perspectives and programmatic ideas that could lead to new European-wide comparative research projects. In general, I think there are a few ways to proceed. A wide-ranging study that includes all European countries is of course the ultimate goal, but not within reach soon, due to the lack of fundamental research in several European countries and also financial means. More realistic would be to start with collecting data systematically and conduct series of comparative case studies in which we explore some important questions and approaches. What follows are a few examples of what might be attempted.

It would be extremely insightful to chart all the different European regulations over a long time span (1450-1900), both in urban and rural areas, related to the distribution of popular print as well as the freedom of movement of itinerants and street sellers. These regulations had an impact on the naming and framing of genres and book sellers, but they also explain the restrictions and (discontinuity of) successes of popular print in different countries. A good strategy to get a better grasp of regulation in Europe would be to identify major turning points in the organisation of regulation in European countries and regions.

In terms of sociality aggregating biographical information about European distributors would be a precondition for research into social stratification, geographical spread, forms of collaboration, networks and trade practices. Currently, the most extensive international, online tool is probably the CERL Thesaurus. ${ }^{90}$ This database contains metadata about European book people during the hand press period (1450-c.1830). Aside from that there are comprehensive national projects as well. For the British Isles online data are available via the British Book Trade Index and the Scottish Book Trade Index. ${ }^{91}$ Dominique Varry created a site with 'gens du livre' in Lyon. ${ }^{92}$ The Dutch online system Bibliopolis also provides access to biographical data of booksellers. ${ }^{93}$

9o See https://data.cerl.org/thesaurus/_search. The CERL thesaurus contains the records of the database of Dutch and English itinerant traders I compiled for my vidi project. To be aggregated with the key word 'Itinerant trader'.

91 ввтг: http://bbti.bodleian.ox.ac.uk/; sBті: https://data.cerl.org/sbti/_search.

92 See http://dominique-varry.enssib.fr/gens-du-livre.

93 https://www.bibliopolis.nl/personen?lang=en. 
Alongside the digital sources, there are several substantial biographical lists in printed form produced by renowned European scholars. There is important material for Italy, ${ }^{94}$ France ${ }^{95}$ and Spain. ${ }^{96}$ Bringing this dispersed material together in one database (CERL for instance) in a standardized form would be wonderful achievement and an important impetus for further research.

Due to the large differences between urban and rural forms of distribution, a more profound comparison between some large European cities and rural areas, would help us to see how social-economic circumstances, grades of literacy, political conflicts and the regulation of the local book trade stimulated and hindered the distribution of popular print. In order to contextualise and visualise geographical and spatial differences and features, digital humanities tools and infrastructures such as geo-referencing and GIS could help us to select contrasting regions and plot distribution patterns. A good example and state of the art is the Online Database Archive of the Société Typographique de Neuchâtel, that provides the opportunity to create your own geographical charts of distribution. ${ }^{97}$

It would surely be worthwhile to apply the more inclusive concept of dissemination instead of distribution, and initiate more in-depth case studies such as those of Carnelos (Venice), Salzberg (Venice), Deen (Amsterdam) Darnton (Paris) and Dall'Aglio et al. (several Italian cities). In these studies, print is part of a more diverse oral, performative and handwritten multimedia system in which ideas, narratives and opinions are disseminated. To what extent was print culture part of a wider 'media ensemble' in different European cities and can we identity which media was pivotal. ${ }^{98}$ This type of research would also

94 See for Italy M. Santoro (ed.), Dizionario degli editori, tipografi, librai itineranti in Italia tra Quattrocento e Seicento, 3 vols. (Pisa/Roma 2013); A. Milano (ed.), Commercio delle stampe e diffusione delle immagini nei secoli XVIII e XIX: Trade and Circulation of Popular Prints During the XVIII and XIX Centuries (Rovereto 2008); Laura Carnelos is currently compiling a database of Italian blind authors and singers. See a digital collection of the works of the most famous Italian street singer http://badigit.comune.bologna.it/GCCroce/index .html.

95 F. Barbier, S. Juratic \& A. Mellerio, Dictionnaire des imprimeurs, libraires et gens du livre à Paris (1701-1789) (Genève 2007); F. Barbier, 'Lumières du Nord: Imprimeurs, libraires et "gens du livre" dans le Nord de la France au XVIII e siècle (1701-1789)', in: Dictionnaire prosopographique (Genève 2002).

96 A. Rodríguez-Moñino, Nuevo diccionario bibliográfico de pliegos sueltos poéticos (siglo XVI) (Madrid 1997); F. Aguilar Piñal, Romancero popular del siglo XVIII (Madrid 1972); Juan Gomis has collected biographical data about printers and pedlars in the 18th century.

97 See http://fbtee.uws.edu.au/stn/interface/.

98 See M. Rospocher \& J. Salman, 'Introduction: Crossing Borders, Crossing Cultures', in: Rospocher, Salman \& Salmi (eds.), op. cit. (n. 10), p. 2; D. Bellingradt, 'The Dynamic of 
put the impact of popular print (such as pamphlets) on public opinion more in perspective.

Finally, the fascinating but complex field of visual and fictional representations of itinerant book sellers begs for large-scale, Europe-wide digitisation of visual and textual sources, stored in widely accessible repositories with text mining, visualisation and image recognition tools. Even if this would be achieved, interpreting these sources would still be a challenge, due to the diversity and quantity of all these plays, novels, songs, paintings, engravings, drawings, tiles, and statues. Again, the best way to go about it would surely be to start by comparing countries where these sources are already digitised and made accessible. I am sure this will inspire other institutions, collections and scholars to follow in due course.

Communication and Media Recycling in Early Modern Europe: Popular Prints as Echoes and Feedback Loops', Rospocher, Salman \& Salmi (eds.), op. cit. (n. 10), pp. 9-32. 